\title{
Evaluation of Knowledge and Experience of Dentists of São Paulo State, Brazil about Cardiopulmonary Resuscitation
}

\author{
Heron Fernando de Sousa GONZAGA ${ }^{1}$ \\ Leonardo $\mathrm{BUSO}^{2}$ \\ Maria Augusta JORGE ${ }^{3}$ \\ Lúcia Helena de Sousa GONZAGA ${ }^{4}$ \\ Marcelo Donizetti CHAVES ${ }^{5}$ \\ Oslei Paes de ALMEIDA ${ }^{5}$ \\ ${ }^{1}$ Research Center - Center of Higher Education of Dracena-CESD, Dracena, SP, Brazil and \\ Department of Oral Pathology, Faculty of Dentistry, University of Campinas, Piracicaba, SP, Brazil \\ ${ }^{2}$ Department of Dental Materials and Prosthesis, Faculty of Dentistry of São José dos Campos, UNESP, SP, Brazil \\ ${ }^{3}$ Research Center - Center of Higher Education of Dracena - CESD, Dracena, SP, Brazil \\ ${ }^{4}$ Department of Restorative Dentistry, Faculty of Dentistry, University of Marilia, SP, Brazil \\ ${ }^{5}$ Department of Oral Pathology, Faculty of Dentistry, University of Campinas, Piracicaba, SP, Brazil
}

\begin{abstract}
This work describes the knowledge and experience of dentists about cardiopulmonary resuscitation (CPR). A total of 182 dentists from São Paulo State, Brazil were interviewed: $59 \%$ judged themselves able to define CPR, although only $46 \%$ had a correct concept; $54 \%$ believed himself to be able to perform CPR, however, none of them referred to have received practical training in CPR; $3 \%$ of the interviewed professionals mentioned the occurrence of cadiopulmonary arrest in their dental office. It was concluded that dental surgeons in Brazil should be better trained for medical emergencies that can occur in the dental office.
\end{abstract}

Key Words: dentistry, cadiopulmonary arrest, cardiopulmonary resuscitation.

\section{INTRODUCTION}

Cardiopulmonary arrest (CPA) is a sudden stop of respiratory movement or effective circulation. Cases of patients with chronic diseases or terminal malignancies must be excluded (1). CPA is the most urgent of emergencies, and consequently, diagnosis must be done as soon as possible. The tolerance of the heart to anoxia is relatively high, but the central nervous system will show irreversible lesions if anoxia lasts more than 3 to 4 minutes (2).

Though unusual, there are reports of deaths due to CPA in dental offices during dental treatment (3-5). Little has been published about competence of dentists to deal with CPA, or the occurrence of resuscitation emergencies in dental practice (6-9).

All health professionals, including dentists, must be well prepared to attend to and collaborate with medical emergencies. Besides training in basic techniques of resuscitation, such as mouth-to-mouth respiration combined with cardiac massage, other procedures can be useful. Dentists should have at hand and be trained to use a laryngoscope, oropharyngeal tube, Ambu mask, oxygen balloon and drugs, such as adrenaline.

Believing that dentists should be well trained to perform cardiopulmonary resuscitation (CPR), this work was done to investigate their CPA experience in the dental office and their CPR knowledge.

\section{MATERIAL AND METHODS}

A total of 182 dentists from São Paulo State, Brazil were questioned regarding their experience and 
knowledge about CPR and occurrence of CPA in their offices from May 1997 to May 1999. The dentists were advised to answer the questions without resorting to literary material or other professionals.

\section{RESULTS}

The results of this survey among 182 Brazilian dentists about CPA are shown in Tables 1, 2 and 3. Fifty-nine percent considered themselves to know what CPA is, but only $46 \%$ answered correctly the concept of CPA. About half of the dentists (54\%) considered they were able to perform CPR. Although $86 \%$ had received information about CPR, most of them had not received practical training for resuscitation.

\section{DISCUSSION}

Cardiopulmonary arrest may occur in the dental office $(3,4,10)$, and death has been reported (3-5). There are few surveys about the subject and none with Brazilian dentists. The lack of training and inability to

Table 1. Distribution of 182 dentists about their concept of cardiopulmonary arrest (CPA). Their opinion about knowing or not knowing what is CPA (self-judgement) was compared with their answer about CPA (correct or incorrect concept).

\begin{tabular}{|c|c|c|c|}
\hline $\begin{array}{l}\text { Self- } \\
\text { judgement }\end{array}$ & $\begin{array}{l}\text { Correct } \\
\text { concept }\end{array}$ & $\begin{array}{l}\text { Incorrect } \\
\text { concept }\end{array}$ & Total \\
\hline I know & $82(45 \%)$ & $26(14 \%)$ & $108(59 \%)$ \\
\hline I do not know & $2(1 \%)$ & $72(40 \%)$ & $74(41 \%)$ \\
\hline Total & $84(46 \%)$ & $98(54 \%)$ & $182(100 \%)$ \\
\hline
\end{tabular}

Data are reported as number and percent.

Table 2. Distribution as reported by 182 Brazilian dentists about their capacity to perform cardiopulmonary resuscitation (CPR) and to have information about this emergency. None of the dentists reported that they had practical training for resuscitation.

\begin{tabular}{lcc}
\hline CPR & Capable & Information \\
\hline Yes & $98(54 \%)$ & $156(86 \%)$ \\
No & $76(42 \%)$ & $22(12 \%)$ \\
Not Answered & $8(4 \%)$ & $4(2 \%)$ \\
\hline
\end{tabular}

Data are reported as number and percent. cope with these emergencies can lead to tragic and legal consequences.

Chapman et al. (9) found that $64 \%$ had received information about the subject versus $86 \%$ found in this study. Theoretical information with demonstrations, but without practice, probably is not enough to assure CPR competence. Comparing our data with the literature, it was observed that as to theoretical knowledge Hussain et al. (7) found correct concept in $52 \%$ of the assessed professionals versus $46 \%$ in our study. Chapman et al. (6) and Hussain et al. (7), evaluating dentists about CPR, reported that all failed the practical assessment. As to self-judgement in being capable of performing CPR, our results were similar to the literature, showing an average above 50\% $(6,9)$. CPR techniques must be taught and emphasized for health professionals in developing countries such as Brazil. In developed countries, with a higher level of education, this probably could be extended to most of the population (11). Nevertheless, the literature about CPR shows that the subject is of high concern in dentistry in Australia (6), Italy (12), the United Kingdom (7), and the USA $(13,14)$.

A total of $12 \%$ of the 182 surveyed dentists reported to have witnessed CPA outside the dental office, but only $3 \%$ (5 of 182) had patients with CPA in their dental office. In fact, these 5 patients died in the dental office. We could not confirm this information because the questionnaires were not signed, but we consider them to be correct. This observation is extremely relevant, and it emphasises the importance of the subject and the necessity for a better discussion and consciousness of the dental class. In relation to having had an actual experience in cardiac arrest in the office, in 1995 Chapman et al. (6) reported 5\% versus 3\% in our work in contrast to $14.2 \%$ reported by Chapman et al. (9) in 1997. The participation of Educational Institu-

Table 3. Responses to questions about CPA by 182 dentists. Have you seen any person suffering CPA? (observation). Has any patient in your dental office suffered CPA? (experience).

\begin{tabular}{lcc}
\hline CPA & Observation & Experience \\
\hline Yes & $22(12 \%)$ & $5(3 \%)$ \\
No & $160(88 \%)$ & $177(97 \%)$ \\
\hline
\end{tabular}

Data are reported as number and percent. 
tions to improve the training of students and professionals for CPR and other medical emergencies that can occur in the dental office is also necessary.

Brazilian dentistry has reached a high level of qualification in various specialities of dentistry. A better knowledge of medical emergencies is a necessary step for further development of dentistry in Brazil, and to provide better and safer service for the population.

\section{ACKNOWLEDGEMENTS}

This study was supported by FAPESP, SP, Brazil.

\section{RESUMO}

Este trabalho descreve o conhecimento e experiência dos cirurgiões dentistas em reanimação cárdio-respiratória (RCR). Foram entrevistados 182 cirurgiões dentistas do Estado de São Paulo, Brasil: 59\% julgava-se capaz de definir RCR, embora somente $46 \%$ tivesse um conceito correto; $54 \%$ acreditava ser capaz de realizar RCR, no entanto nenhum deles referiu ter recebido treinamento prático em RCR; 3\% dos entrevistados mencionou a ocorrência de parada cárdio-respiratória no consultório odontológico. Concluiu-se que os cirurgiões dentistas brasileiros deveriam ser melhor treinados em emergências médicas que podem ocorrer nos consultórios odontológicos.

\section{REFERENCES}

1. Russo AC, Nogueira DP, Ribeiro IJ, Lane JC, Martins JEC,
Carvalho JGF. Pertubações causadas por agentes físicos. In: Manual de Clínica Médica. Gonçalves EL, Oliveira HL, Kieffer L, Germek AO, Pereira VG. eds. 1st. edn. Rio de Janeiro: Guanabara Koogan. 1980. p. 1533-1557.

2. Vane LA. Parada cardíaca e reanimação. In: Temas de Anestesiologia. Bras JRC, Yong LC, Vane LA, Pinheiro NS, Viana PTG, Castiglia YMM. eds. 3rd edn. Botucatu: Faculdade de Medicina de Botucatu. 1983. p 319-343.

3. Brahms D. Death in the dentist's chair. Lancet 1989;2:991-992.

4. Hunter PL. Cardiac arrest in the dental surgery. Br Dent $J$ 1991;170:284.

5. McCarthy FM. Emergencias en odontología. Buenos Aires: WB Saunders. 1972. p. 281-292

6. Chapman PJ. A questionnaire survey of dentists regarding knowledge and perceived competence in resuscitation and occurrence of resuscitation emergencies. Aust Dent J 1995;40:98-113.

7. Hussain I, Matthews RW, Scully C. Cardiopulmonary resuscitation skills of dental personnel. Br Dent J 1992;173:173-174.

8. Chate RA. Evaluation of a dental practice cardiopulmonary resuscitation training sheme. Br Dent J 1996;181:416-420.

9. Chapman PJ. Medical emergencies in dental practice and choice of emergency drugs and equipment: a survey of Australian dentists. Aust Dent J 1997;42:103-108.

10. Fletcher JM, Kramer LD. An in practice training scheme for cardiopulmonary ressuscitation (CPR). Br Dent J 1992;176:252253.

11. Markarian S. CPR in a dental setting: a step-by-step sequence. General Dentistry 1986;34:134-137.

12. Montebugnoli L, Pelliccioni GA. Cardiopulmonary resuscitation in ambulatory dentistry. Dent Cadmos 1990;58:64-79.

13. Akers P. Office emergency preparation. CDS Rev 1993;86:1418.

14. Young ER. The dental office medical emergency: What do 1 do? J Can Dent Assoc 1994;60:117-120.

Accepted September 16, 2002 